\title{
Improving Acts Of Participants Care With The Group Small Method Discussion In Madrasah Aliyah Kota Singkawang
}

\author{
Sugianto Adi Saputra ${ }^{1}, \mathrm{R}_{\text {Rusmono }}^{2}, \mathrm{M} \mathrm{Marzuki}^{3}$ \\ \{sugiantoa9876@gmail.com ${ }^{1}$ \} \\ Universitas Negeri Jakarta, Indonesia ${ }^{123}$
}

\begin{abstract}
This action research aims to determine the improvement of morality / morality aspects of curiosity, cooperation, responsibility, tolerance and discipline with the method of small group discussion in Madrasah Aliyah, Singkawang City. Data collection is done by observation and questionnaire techniques, as well as documentation. Analysis and interpretation of data shows that (1) Learning activities using the small group discussion method can improve students' moral / moral aspects: curiosity, cooperation, responsibility, tolerance and discipline, (2) Participation of students in discussions with methods small group discussion in the good and successful category, (3) The attitude of students after participating in learning with the small group discussion method in good category. The results of the study are recommended so that the small group discussion model can be developed at the Singkawang City Islamic Senior High School to improve students' morality.
\end{abstract}

Keywords: Akhlakul Karimah, Action Research, and Small Group Discussion

\section{Introduction}

Moral education is the main education for children, and must be done early. Moral education is a learning process that is carried out consciously by adults to students by transferring moral values and good habituation in order for students to be able to have noble character (al-akhlak al-karimah) in accordance with Islamic teachings (Muhtar, 2016)[1]. Moral education is the process of internalizing noble moral values into students, so that these values are firmly embedded in mindset, speech and practice, and their interactions with God, humans and the universe, (Abudin, 2013)[2].

The word moral has several equivalents. The word that is equivalent or meaningful to morals, is moral, ethics and character. The words moral, moral, ethical or character are equated with manners, morality, or manners (Marzuki, 2009)[3]. Morals are also related to character. In relation to moral education, moral education has the same orientation, namely the formation of character. The difference is that moral education impresses east and Islam, while characters seem western and secular, and not a reason to be opposed. In fact, both of them have spaces that complement each other. Even Lickona suggests a close link between character and spirituality (Zubaedi, 2012)[4].

Moral equations with morals, ethics, or character because together discuss good and bad problems of human behavior. (Rosihan Anwar: 2010)[5]. Substantially, ethics, morals and 
morals, are the same, namely the doctrine of good and bad human behavior in relation to God, its relationship with fellow humans and relations with nature.

Good character, consists of three components that are flowering, namely: Knowledge of moral(moralknowing), the moral sense(moralfeeling), and moral behavior(moralAction) (Lickona: 2013)[9]. According to Lickona, the moral / moral values instilled in students includehonesty, justice, tolerance, caution, self-discipline, help, compassion, cooperation, courage, and a number of democratic values. These special values are a form of infection and / or responsibility or assistance to act effectively and responsibly.

The problem is, the learning process is a process of internalizing moral values. However, the teacher-centered learning process makes passive learning. Students are not actively involved in learning. Inetraction of learning is in the same direction, so that the students' moral virtues in aspects of curiosity, cooperation, responsibility, tolerance and discipline are hampered.

Focused action research is issues that arise in the community that require urgent handling and solutions, as explained below, Action Research is a special form of research. This is a problem-based investigation in certain problems that exist in the community. Usually, focus on issues that arise in the community that need urgent care and solutions, (Kafu, 2015)[12].

The results of Ishwar's[13] research that action research contribute positively in improving their professional practice in school,remember that teachers in office show great satisfaction with the course, the methodologies involved in action research may have contributed positively in terms of improving their professional practice in school. The results of Rodney's [14]show studythat action research is a growing tradition to improve teacher practice and student learning outcomes, and it draws from a variety of methods for collecting and analyzing data.

According to Lesha[15] that action research is very appropriate for its main purpose is to help teachers as researchers solve problems. Although some might criticize that action research is informal research because teachers are not academic researchers, it is believed that action research is suitable for education because its main goal is to help teachers as researchers solve their teaching problems in action.

The method used in learning in this action research is small group discussion. Metode small goup discussion, is very reasonable, namelycan improve understanding, involve students actively and improve critical thinking skills, (Genya (2012)[16]. The steps for small group discussion according to Dobson are as follows: (1) Divide the class into small groups of three to six people each Give different groups of discussion topics that will require description of several important points: Ask a student in each group to write these points when they arise from the discussion by group members, (2) Allow the groups to discuss their respective topics for at least 10 minutes. After completing their discussion, they must choose a spokesperson who will report the group's collective thoughts to the entire class, (3) Call to the spokesperson for one group After he gives a short presentation (five minutes or more), the class member must ask him or someone others in the group.

\section{Method}

The procedure of this study used the Kemmis and Mc Taggart action models[17]. Kemmis and Taggart models, in the form of cycles. The research data set can be accessed in osf.io Open Science Framework. One cycle consists of three components which include, 
namely, (1) planning ((planning), (2) actions (acting), (3) observation (observation), (4) reflection (reflecting), with the procedure for implementing actions can be seen in Figure 1. below:

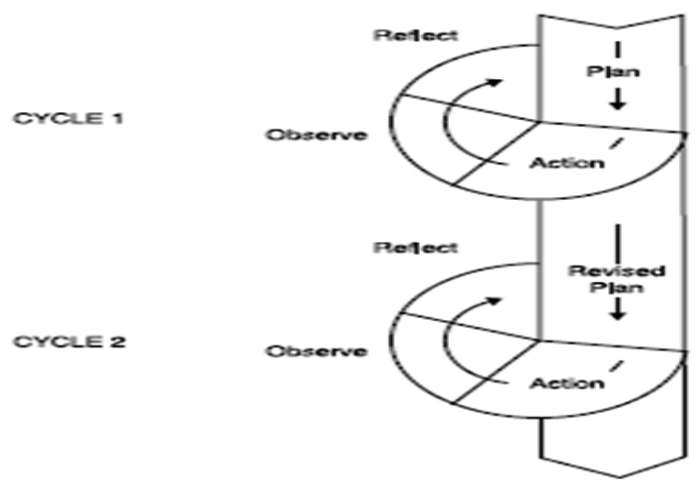

Fig. 1. : Procedure for Implementing theAction Research

\subsection{Action Research Success Criteria}

The criteria for the success of this action research are the achievement of akhlakul karimah on the aspects of curiosity, cooperation, responsibility, tolerance and discipline with the small group discussion method for class XII students in the Singkawang city of Islamic madrasah. To facilitate interpretation, use analysis data to see the success of teachers and students based on the competencies set by the Ministry of National Education (Aqip, 2010), as follows:

- $\quad$ Value $91-100=$ Very good (A) succeed

- Value $76-90=$ Good (B) succeed

- Value 55 - 75 = Enough (C) has not been succeeded

- Value 0 - 54 = Less (D) is not successful,

\section{Results}

The results of the study with observations on the learning activities of the Qur'an Hadith with themethod small group discussion in MAN, are shown in the following table 1. :

Table 1. Score Recapitulation of Observation Results of Al-Qur'an Learning Activities Hadith in MAN Model Cycle I, Cycle II and Cycle III

\begin{tabular}{llrrr}
\hline No & $\begin{array}{c}\text { Acquisition The Activities Scoring of The Quran Hadits With the } \\
\text { Small group Discussion Method }\end{array}$ & $\begin{array}{c}\text { Cycle } \\
\text { I }\end{array}$ & $\begin{array}{c}\text { Cycle } \\
\text { II }\end{array}$ & $\begin{array}{c}\text { Cycle } \\
\text { III }\end{array}$ \\
& Teacher'Origin & Score & Score & Score \\
1 & MAN Model & 69 & & \\
\hline
\end{tabular}


Table 1. shows an increase in scores on Al-Quran learning activities of hadith from cycle I to cycle II to cycle III. In the third cycle there was an increase in scores with a very good category.

Table 2. Recapitulation of Observation Results of Student Participation in Discussions with Small Group Discussion Methods in MAN Models, Cycles I, II and III

Score Result Of Participation Observation Of Participants in Cycle III

\begin{tabular}{|c|c|c|c|c|c|c|c|}
\hline \multirow[t]{2}{*}{ No } & \multirow{2}{*}{$\begin{array}{c}\text { Student } \\
\text { Origin }\end{array}$} & \multicolumn{5}{|c|}{ The Aspects That Action is Observed } & \multirow[t]{2}{*}{ Action } \\
\hline & & Curiosity & Cooperation & Responsibility & Tolerance & Disipline & \\
\hline \multirow[t]{4}{*}{1} & MAN & 79 & 82 & 89 & 94 & 92 & 7 \\
\hline & Model & 86 & 86 & 89 & 94 & 92 & 8 \\
\hline & Amount & 165 & 168 & 178 & 188 & 184 & \\
\hline & Average & 83 & 84 & 89 & 94 & 92 & \\
\hline
\end{tabular}

Table 2. shows an increase in scores of student participation in discussion activities using the small group discussion method. Obtaining a score of participation in each student. Increased scores in good and successful categories.

Data from the questionnaire scores of students after following the discussion by the method of small group discussion in MAN, in the following table 3. :

Table 3. Score Questionnaire Attitudes of Students After Al-Qur'an Learning Hadith with Small Group Discussion Method in MAN Model Cycle I, Cycle II and Cycle III

Questioner Scores Attitudes Of Students After Learning With The Small Group Discussion

\begin{tabular}{ccccccc} 
& & \multicolumn{5}{c}{ Measured Aspects } \\
\cline { 3 - 7 } No & $\begin{array}{c}\text { Student } \\
\text { Original }\end{array}$ & Score & Score & Score & Score & Score \\
1 & MAN & 88 & 85 & 87 & 85 & 83 \\
& Model & & & & & \\
\hline
\end{tabular}

Table 3. shows the acquisition score of students' attitudes after participating in learning with the method of small group discussion on aspects of wanting to know, cooperation, responsibility, tolerance and discipline. 


\section{Discussion}

The results of the study show that the learning activities of the Al-Quran hadith by the method of small group discussion, can increase the moral virtue of the aspects of curiosity, cooperation, responsibility, tolerance and discipline of students.

The success of the research using the small group discussion method, in accordance with the results of the study by Nachal Annamalay, et al.that small group discussion is an interactive, friendly learning method that can connect interactions between teachers and improve students' communication skills. Small group discussion is an effective method than traditional learning methods. Small groups have improved students 'communication and interaction skills (Annamalay: 2015)[18]

The success of small group discussion results of Antoni's research shows that thelearning method small groupanalyzed can improve students' speaking skills. This method can also increase interaction between teachers and students, (Rivi Antoni, 2014)[19]

The results of Ali Tabrizi's study, which shows that themethod small group discussion can improve learning skills more effectively than traditional methods,( Ali Tabrizi, 2015)[20].

research results Coffey's, that the method ofmall group discussion, can improve students' understanding and involvement, and improve critical thinking skills, (Coffey. 2012)[16].

The results of the Chetana study show the small group discussion method of facilitating active learning for students in understanding more about an object, as well as the ability to develop communication, (Chetana, 2014)[21].

The results of expert research on the success of small group discussions include improving students' thinking power, connecting interactions and communication between student teachers, students and students. Small group discussions facilitate active learning and improve learning skills more effectively. The small group discussion method places students actively involved in learning, so that learning is centered on students.

This is in accordance with the results of the review Judith Bennett, who argues that small group discussion is highly recommended as an important teaching approach in school science for several years, partly arises from more general movements towards student-centered learning, and partly as a means of drawing recommendations from constructivist research, which is considered it is very important to give students the opportunity to articulate and reflect on their own ideas scientific phenomena.

The results of the study on the participation of students in the discussion with the method of small group discussion on aspects of curiosity, cooperation, responsibility, tolerance and discipline.

\subsection{The curiosity}

The curiosity of the students, in accordance with the opinion of Pluck, G. and Johnson[22], who explained that wanting to know in accordance with the opinion of Pluck, G. and Johnson, which explains that, curiosity is an aspect of motivation that has the potential to encourage students to improve learning. In other words, that curiosity is something that someone feels to know about it. According to Caroline B. Marvin and Daphna Shohamy[23], curiosity is, is an aspect of motivation that has the potential to encourage students to improve learning.

Curiosity becomes important for students. Curiosity encourages students to actively seek out various sources to find out something. Curiosity encourages students to study hard and expand knowledge; 
The results of Busmin Gurning and Aguslani's research[24], high curiosity will have a great desire to question gaps in learning, seek information and knowledge of exploration, answer certain questions and good attention in learning while students with low curiosity will appear otherwise.

\subsection{Cooperation}

The aspect of cooperation is through themethod small group discussion, achieving improvements in the good and successful categories. According to Johnson \& Johnson[25], Cooperation is working together to achieve goals. This is in accordance with the results of the research of Hulya Guvenc[26], that cooperation in learning has a positive effect on learning activities and student performance. According to Ranjani Balaji[27] Iyer's research, cooperative learning promotes thinking and grows student interaction. Activities based on cooperative learning are creative, thought-provoking and interactive and offer ideas for how children can carry out values in practice and find answers within themselves. Cooperative learning can be used to improve and promote students' higher achievement.

\subsection{Responsibility}

Aspects of responsibility, have achieved an increase, increase and success according to Fitzpatrick[28], that, "Social responsibility first means that someone recognizes, accepts, and acts on public responsibility towards one's society. More specific and more realistic, this requires responsibility to people and interests that will be affected by one's actions. The results of Rukiyati's [29]research show that responsibilitymeans feeling the importance of the value of responsibility. The value of responsibility is manifested in participating in group work. The values of responsibility arise during the learning process, namely the value of familiarity, breadth of insight, creativity, and the atmosphere of learning to be more active.

\subsection{Tolerance of}

Tolerance aspects of students in good and successful categories. This is in accordance with the results of the research of Safina[30], that tolerance in human life is considered an urgent necessity. In this case, it is necessary to encourage systematic and rational methods of teaching tolerance. Policies and programs in the field of education must help improve mutual understanding, solidarity and tolerance, both between individuals and between ethnic groups, religions, social, cultural and linguistic as well as countries.

The results of Baklashova TA's[31] research show that tolerance for tolerance is seen as the quality of a person who is first formed in the process of socialization throughout life and manifests itself in various fields. The significant role of education, combined with sports and social events and the personal development of each participant is a proven process. Ethnic, social and personal tolerance is studied and analyzed.

\subsection{Discipline}

The results of Masthurhah Ismail's [32]research that aspects of discipline, though, this study has developed a strategy to overcome the problem, the problem still persists. This may be because the approach used does not consider a balanced approach that includes elements of emotional, mental, and spiritual aspects.

Research results Yussi's[33], good vocational secondary schools prepare students to develop the ability to work independently, show professional attitudes in the workplace, and be productive who need good learning outcomes to make it happen. learning outcomes serve as a benchmark for student success. The results showed that discipline and learning motivation 
significantly contributed to student learning. High discipline increases learning motivation which leads to improved learning outcomes.

\section{Conclusion}

The conclusions of this study are:

1. Learning activities with Al-Quran hadith using themethod small group discussion can improve students' morality in aspects of curiosity, cooperation, responsibility, tolerance and discipline.

2. Participation of students in discussions with themethod small group discussion in good and successful categories, on aspects of curiosity, cooperation, responsibility, tolerance and discipline.

3. The attitude of students after following the learning with themethod small group discussion in good and successful categories on aspects of curiosity, cooperation, responsibility, tolerance and discipline obtained through questionnaire scores.

\section{References}

[1] D. S. dan S. B. Muhtar, "Konsep Pendidikan Akhlak dan Dakwah dalam Perspektif DR. KH. Zakki Mubarak, MA,”, J. Stud. Al-Qur'an, vol. 12, no. 2, 2016.

[2] A. Nata, Kapita Selekta Pendidikan Islam. Jakarta: Raja Grapindo, 2013.

[3] Marzuki, "Pembinaan Akhlak Mulia dalam Berhubungan Antar Sesama Manusia dalam Perspektif Islam," J. Humanika, vol. 9, no. 1, 2009.

[4] Zubaedi, Desain Pendidikan Karakter: Konsepsi dan Aplikasi dalam Lembaga Pendidikan. Jakarta: Kencana Preanada Media, 2012.

[5] R. Anwar, akhlak tasawuf. Bandung: Pustaka Setia, 2010, 2010.

[6] dan M. S. Khalidah, Rohani Salleh, "A Study on the Level of Ethics at a Malaysian Private Higher Learning Institution: Comparison betweenFoundation and Undergraduate TechnicalbasedStudents," J. Basic Appl. Sci., vol. 10, no. 5, 2010.

[7] J. Suprihatinungrum, "Guru Profesional Pedoman Kinerja, Kualifikasi \& Kompetensi Guru." Jogjakarta: Ar-Ruzz Media, 2013.

[8] B. Maunah, "Implementasi Pendidikan Karakter dalam Pembentukan Kepribadian Holistik Siswa," J. Pendidik. Karakter, vol. 5, no. 1, 2015.

[9] T. Lichona, Mendidik untuk Membentuk Karakter: Bagimana Sekolah dapat Memberikan Pendidikan tentang Sikap Hormat dan Tanggung Jawab, terjemahan Juma Abdu Wamaungo. Jakarta: Bumi Aksara, 2013.

[10] V. Koshy, Action Reseacrh for Inproving Practise: Practical Guide. London: Tausan Oaks, 2005.

[11] M. and G. B. Vaughan, "Action research in graduate teacher education: a review of the literature 2000-2015," J. Educ. Action Res., vol. 24, no. 2, 2016.

[12] Patrick A Kafu, "Action Reasearch Promotion of Access Quality and Equty in Education for Development in Africa," J. Int. Educ. Leraning Dev., vol. 3, no. 2, 2015.

[13] Govinda Ishwar Lingam, "Action Research: Promise and Potential for Improving Teacher Professional Practice and the Learning Organisation School of Education The University of the South Pacific Laucala Campus,” J. Contemp. Res., vol. 2, no. 4, 2012.

[14] Rodney Bealieu, "Phenomenography: Implications for Expanding the Educational Action Research lens," J. Action Res., vol. 18, no. 2, 2017.

[15] Jonida Lesha, “Action Research in Education,” J. Eur. Sci., vol. 10, no. 13, 2014. 
[16] Genya Coffey, "Literacy and Technology: Integrating Technology with Small Group, Peer-led Discussions of Literature," J. Elem. Educ., vol. 4, no. 2, 2012.

[17] R. M. Taggart, Action Research: A Short Modern History. Australia: Deakin University, 1993.

[18] R. M. dan Y. P. Nachal, Annamalay, "Small Group doscussion: Studen Pespectives," J. Appilied Basic Med. Res., vol. 5, no. 1, 2015.

[19] Rivi Antoni, “, Teaching Speaking Skill Through Small Group Discussion Technique,”, J. Educ. Islam. Stud., vol. 5, no. 1, 2014.

[20] A. T. Tabrizi, "Efek of small Group Discussion In Residency Education Versus Conventional Education," J. Res Dev Educ, vol. 5, no. 1, 2015.

[21] Chetana.P.Hadiman, "Effectiveness of Small Group Discussion Sessions in Teaching Biochemistry for Undergraduate Medical Students," J. Med. Educ., vol. 8, no. 1, 2014.

[22] G. and J. Pluck, "Stimulating Curiosity to Enhance Learning, Journal Education Science and Psychology," J. Educ. Sci. Psychol., vol. 2, no. 19, 2011.

[23] C. and R. Caroline B. Marvin and Daphna Shohamy, "Valence Predicts Choice and Information Prediction Errors Enhance Learning,” J. Exp. Psychol., vol. 145, no. 3, 2016.

[24] dan A. S. Gurning, Busmin, "The Effect of Teaching Strategies and Curiosity on Students' Achievement in Reading Comprehension," J. English Lang. Teach., vol. 10, no. 11, 2017.

[25] Johnson \& Smit, "Cooperative Learning: Improving University Instruction By Basing Practice On Validated Teory,” J. Excell. Univ. Teach., 2013.

[26] Hulya Guvenc, “, The Effects of Cooperative Learning and Learning Journals on Teacher Candidates' Self-Regulated Learning,” Journal, Educ. Sci., 2010.

[27] Ranjani Balaji Iyer, "Relation between Cooperative Learning and Student Achievement," J. Educ. Inf. Student, vol. 3, no. 1, 2013.

[28] Kathy Fitzpatrick, "Toward a Professional Responsibility Theory of Public Relations Ethics," J. Mass Media Ethics, vol. 16, no. 2, 2001.

[29] P. P. Rukiyati, Y. Ch. Nany Sutarini, "Penanaman Nilai Karakter Tanggung Jawab Dan Kerja Sama Terintegrasi Dalam Perkuliahan Ilmu Pendidikan,” J. Pendidik. Karakter, vol. 4, no. 2, 2014.

[30] Rezida N. Safina, "The Formation of Students' Tolerance in a Multi-Ethnic School," J. Environ. Sci. Educ., vol. 11, no. 3, 2016.

[31] B. T.A, "The Effects of Education on Tolerance: Research of Students' Social and Ethnic Attitudes," J. Soc. Sci., vol. 6, no. 1, 2015.

[32] M. S. M. Y. Masthurhah Ismail, Puteri Rohani Megat Abdul Rahim, "Educational Strategies to Develop Discipline Among Students from the Islamic Perspectives," Procedia - Soc. Behav. Sci., vol. 107, 2013.

[33] Yussi, "The Contribution Of Vocational Students' Learning Discipline, Motivation And Learning Results,” J. Environ. Sci. Educ., vol. 12, no. 5, 2016. 